\title{
A Study on Problems and Prospects of Rural Co-Operative Marketing
}

\author{
Jyothi, K.C.* \\ * Research Scholar, DOS in Economics, Kuvempu University, Shankaraghatta - 577 451, Shimoga
}

\section{Introduction}

Rural marketing facilitate flow of goods and service from rural producers to urban consumers at possible time with reasonable prices, and agriculture inputs/ consumer goods from urban to rural. Marketing as a function has started much earlier when civilization started but not recognized as marketing. All economy goods are marketed in terms of goods and services (Barter system). Now money is being practiced as a good exchanging medium. The market may be a street, or a small town! metropolitan city, Developments in infrastructure, transport, and communication facilities has increased the scope of the rural market.

\section{Rural Co-operative Marketing}

Around 700 million people, or $70 \%$ of India's population, live in 6,27,000 villages in rural areas. $90 \%$ of the rural population is concentrated in villages with a population of less than 2000. Rural marketing is as old as the civilization. Surplus of agro - products are exchanged in earlier days in the barter system. The introduction of currency, transport, and communication has increased the scope of rural co-operative market.

Current agricultural marketing system in India is the outcome of several years of government intervention. Agricultural marketing scenario in India has undergone conspicuous changes during the last 50 years, owing to the increased marketed surplus; increase in urbanization and income levels and consequent changes in the pattern of demand for marketing services; increase in linkages with distant and overseas markets; and changes in the form and degree of government intervention. While the policy framework that influenced the structure, conduct and performance of agricultural marketing is discussed in the third section, some basic features of the system are presented here.

\section{Co-operative Marketing}

Another major improvement for rural producers is the formation of cooperative societies. Farmer's common interest helped to increase the incomes of the farmers and avoid exploitation of the middlemen. There are about five lack cooperatives working but very few cooperative societies in selected areas like Dairy, sugar, oil seeds, Mahagrape in Maharastra, tomato growers in Punjab etc. succeeded in cooperative processing industry.

\section{Marketing Channels}

In India, agricultural commodities move from the farm gate to consumers through several channels. Marketing channels for agricultural commodities vary from commodity to commodity but can be broadly divided into four groups viz., (a) direct from fanners to consumers; (b) though public agencies or cooperative organizations; (c) through private wholesalers and retailers; and (d) through processors. Some important characteristics and changes in marketing channels witnessed during the last fifty years are as follows:

1. The proportion of total marketed surplus going directly from farmers to consumers continues to be small.

2. The role of transporters and processors in the marketing channel has considerably increased.

3. Specialization of traders in agricultural marketing, both in terms of commodity or marketing functions has shown an increasing tendency.

4. The length of marketing channel has tended to increase due to increase in demand for value-added services and geographic expansion of markets.

5. The share of private trade in handling marketed surplus has continued to be large. Taking all agricultural commodities together, the marketed surplus handled by cooperatives has been estimated as 10 percent, and by public agencies 10 percent. The private trade handles around 80 percent of the total marketed quantities of agricultural commodities (Acharya, 1994).

6. Realizing that the marketing channels for perishable fresh farm products should be as short as possible, and to eliminate intermediaries, direct marketing by farmers has been encouraged during the last one decade. Several states took initiative and established farmers' markets like APMC (Karnataka), Apni Mandi (Punjab), Kisan Mandi (Rajasthan), Hadaspur Vegetable Market (Pune), Rythu Bazaars (Andhra Pradesh) and Krushak Bazaars (Orissa). The establishment of such farmers markets helped both 
consumers and farmers. The success of such markets depends on the kind of infrastructure and facilities provided at these places and upkeep and maintenance of premises. Nevertheless, this is certainly a better alternative system and needs to be encouraged and promoted.

\section{Problems in Rural Co-operative Marketing}

The rural market offers a vast untapped potential. It is not that easy to operate in rural market because of several problems and also it is a time consuming affair and it requires considerable investments in terms of evolving appropriate strategies with a view to tackle the problems.

The problems are.

\section{Underdeveloped people and underdeveloped markets}

The agricultural technology has tried to develop the people and market in rural areas. Unfortunately, the impact of the technology is not felt uniformly throughout the country. Some districts in Punjab, Haryana or Western Uttar Pradesh where rural consumer is somewhat comparable to his urban counterpart, there are large areas and groups of people who have remained beyond the technological breakthrough. In addition, the farmers with small agricultural land holdings have also been unable to take advantage of the new technology.

\section{Lack of proper physical communication facilities}

Nearly 50 percent of the villages in the country do not have all weather roads. Physical communication to these villages is highly expensive. Even today, most villages in eastern part of the country are inaccessible during monsoon season.

\section{Inadequate Media coverage for rural communication}

A large number of rural families own radios and television sets there are also community radio and T.V sets. These have been used to diffuse agricultural technology to rural areas. However the coverage relating to marketing is inadequate using this aid of Marketing.

\section{Multi language and Dialects}

The number of languages and dialects vary from state to state region to region. This type of distribution of population warrants appropriate strategies to decide the extent of coverage of rural market.

\section{Other Factors Influencing Marketing}

Natural calamities and Market conditions (demand, supply and price), Pests and diseases, Drought or too much rains, Primitive methods of cultivation, lack of proper storage facilities which exposes grain to rain and rats, Grading, Transport, Market Intelligence (up to date market prices to villagers), Long chain of middlemen (Large no. of intermediaries between cultivator and consumer, wholesalers and retailers, Fundamental practices (Market Dealers and Commission Agents get good part of sale of receipts).

\section{Major Losers in Agricultural Marketing}

Small and marginal farmers, $75 \%$ villagers are illiterates or semiliterate, they facing difficulties like proper paper procedures for getting loans and insurance. The farmers facing high interest rates for their credits (Local money lending system). Most of the credit needed for agricultural inputs like seeds, pesticides, and fertilizers.

\section{Online rural market (internet, NICNET)}

\section{Emerging Trends in Markets}

Rural people can use the two-way communication through online service for crop information, purchases of Agri-inputs, consumer durable and sale of rural produce online at reasonable price. Farm information online marketing easily accessible in rural areas because of spread of telecommunication facilities all over India. Agricultural information can get through the Internet if' each village have small information office.

\section{Cost benefit analysis in this sector}

Cost benefit can be achieved through development of information technology at the doorsteps of villagers. Most of the rural farmers need price information of agri-produce and inputs. If the information is available farmers can take quick decision where to sell their produce, if the price matches with local market farmers no need to go near by the city and waste of money \& time it means farmers can enrich their financial strength.

\section{Need Based Production}

Supply plays major role in price of the rural produce, most of the farmers grow crops in particular seasons not throughout the year, it causes oversupply in the market and drastic price cut in the agricultural 
produce. Now the information technology has been improving if the rural people enable to access the rural communication, farmers' awareness can be created about crops and forecasting of ffiture demand, market taste. Farmers can equates their produce to demand and supply, they can create farmers driven market rather than supply driven market. If the need based production system developed not only prices but also storage cost can be saved. It is possible now a days the concept of global village.

\section{Market Driven Extension}

Agricultural extension is continuously going through renewal process where the focus includes a whole range of dimensions varying from institutional arrangements, privatization, decentralization, partnership, efficiency and participation. The most important change that influences the extension system is market forces. There is a need for the present extension system to think of the market driven approach, which would cater the demands of farmers.

\section{Agro- Processing Industry}

India is the second largest producer of fruits and vegetables in the world with an annual production of more than 110 million tonnes of fruit and vegetable only 1.3 percent of the output is processed by the organised sector commercially, the reason higher consumption in fresh form. However, as the packaging, transportation and processing capacities increase, the market for processed fruits and vegetables is projected to grow at the rate of about $20 \%$ per annum. 100\% export oriented units (EOU) and Joint venture units required improving the processing industry.

\section{Kisan Mandi}

There is a need to promote direct agricultural marketing model through retail outlets of fanner's cooperatives in urban areas. The direct link between producers and consumers would work in two ways: one, by enabling farmers to take advantage of the high price and secondly, by putting downward pressure on the retail prices.

\section{Suggestions for Sound Agricultural Marketing in India}

1. Suitable structure of support prices for various farm commodities adjusted from time to time.

2. Adequate arrangement of agricultural produce on support price if the price falls below the level.

3. Regulated infrastructure of markets and warehouses, which ensure fair prices

4. Rural roads must be compliment and coordinate with railways, nearest waterways (port), airports if possible.

5. The efficient marketing is predominantly influenced by efficient distribution system it means products such ultimate consumer in the quickest time possible at minimum cost.

6. The development of communication systems appropriate to rural market may cost up to six times as much as reaching an urban market though established media, need rural communication facilities.

7. The state marketing board or federation or market committees also the producers, traders and sellers have necessarily to be consulted as they have the principle interest towards it $\mathrm{s}$ use.

8. The arrivals of various products such as Food grains Vegetables Dairy products Flowers etc. need speedy transport.

9. Public weighing machines one in each rural market to ensure correct weightment both for farm and nonfarm arrivals. Storage godowns and an office also required.

10. For storage facilities the government should not depend on private agencies to store food grains (National commission on Agriculture recommended).

11. Rural markets need more number of godowns and ancillary platforms for packaging places, market office cum information cell, bank and post office.

12. Rural marketing is the nerve center of a rural economy, rural markets are the channels for the movements of goods and services as well as to promote cultural integration.

13. Agricultural technology must reach all over the country, irrespective of size of land holding.

14. Improve physical communication facility to nook and corner of the country.

15. Land reforms need effectively implemented, because the land is basic asset of rural people.

16. Rural communication must be in regional language and dialects.

17. The existing marketing staff must be increased and adequate training must be given.

18. Extending of financial support for modernization of the agro-processing units is also needed.

19. Processing units should utilise fully capacity.

20. There is need to find out markets for agro-processed products within and out side of the country.

21. The proper packaging technology must be improved. 


\section{Conclusion}

Considering the emerging issues and challenges, government support is necessary for the development of marketing of agricultural produce. The government may adjust suitable budget allocations to rural infrastructure plans, and proper supervision for effective plan implementation. The core areas like transport, communication, roads, credit institutions, crop insurance for better utilization of land and water at appropriate level. The rural people and markets will definitely develop rural income and reduce poverty, on the whole countries economy will boost at an expected level. MANAGE an extension management institution may provide extension services to rural people in crop information, price information, insurance and credit information by using various media. MANAGE may recommend / advice to central and state governments on suitable infrastructure development, current problems in rural markets and problem solving techniques.

\section{References}

[1]. Ambekar Yadav, J.B. (1992). "Communication and Rural Development”, Mittal Publications, New Delhi.

[2]. Gopal Swamy T.P. (1998). "Rural Marketing", Wheeler Publishers, New Delhi.

[3]. Manohar Lal Jalan (1988). "Marketing of Agricultural inputs", Himalaya Publishing House, Delhi.

[4]. Philip Kotlar (1992). "Marketing Management", $8^{\text {th }}$ edition.

[5]. Raj Kumar Singh (1990). "Agricultural Price Policy in India”, Print well Publishers, Jaipur.

[6]. Rajagopal. "Development of Agricultural Marketing in India", Printwell Publishers, Jaipur.

[7]. CMIE Report-97

[8]. Indian agrl. Journal of agril. economics vol. 54 